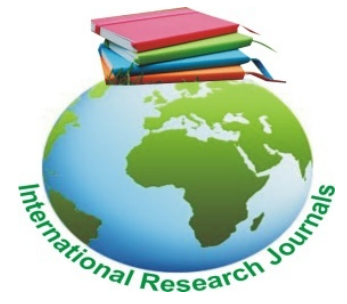

Educational Research (ISSN: 2141-5161) Vol. 7(1) pp. 001 -009, February, 2016

Available online@ http://www.interesjournals.org/ER

DOI: http:/dx.doi.org/10.14303/er.2016.005

Copyright (C) 2016 International Research Journals

Full Length Research Paper

\title{
Availability and use of instructional resources for teaching and learning of English reading skills in secondary schools in Teso North Sub County, Kenya
}

\author{
${ }^{1}$ Macdonald Omuse Omuna, ${ }^{2} \mathrm{Paul}$ Onsare Onchera, ${ }^{3} \mathrm{Charles}$ Kurgatt Kimutai \\ ${ }^{1 / 2 / 3}$ University of Kabianga, Kenya: P.O. Box 2030- 20200, Kericho, Kenya \\ Corresponding Author's E-mail: omusem433@gmail.com
}

\begin{abstract}
In this paper we argue that many learners in Kenya are still not proficient in English reading skills despite going through the English course. The factors associated with the teaching and learning of English reading skills may have been addressed but the impact of instructional resources continues to be a significant issue. This paper discusses the availability and use of instructional resources in the teaching and learning of English reading skills in Secondary Schools in Teso North Sub County, BusiaKenya. The objectives of the study were to explore the availability and use of instructional resources for teaching and learning of English reading skills and examine the correlation between instructional resources and learning of English reading skills. Data was obtained from 440 respondents (400 students and 40 teachers). The study adopted a mixed method approach and data was collected using questionnaires, semi structured interview schedules and classroom observation schedule. The results indicate that textbooks were the most used instructional resources and instructional resources positively correlated with the learning of English reading skills. It was concluded that teachers do not use a variety of instructional resources when teaching English reading skills. It was recommended that teachers who do not use a variety of instructional resources should be sensitized to do so for better results in the English Language.
\end{abstract}

Keywords: Instructional Resources, Reading Skills, Availability, Adequacy.

\section{INTRODUCTION}

In Kenya, English is taught to learners whose First Language is not English. In countries where English is the language of instruction, a proficiency in reading skills is not only a crucial means to gain knowledge but also a means by which advanced studies are taken. In support of this position, Carrell, et al. (1998) cited in (Maingi, 2015) contend that reading is by far the most important of the four macro skills particularly in situations where English is learnt as a second or foreign language. This is true to students in Kenya since the reading skill gives them a wide range of interesting and valuable information as well as a variety of language structures which give them a command in the use of the language (Maingi, 2015). Besides, there are many other benefits of reading skills. For instance, teaching young children reading skills is not only the foundation of improving educational outcomes, but also has important implications for future learning (Gove and Wetterberg, 2011; Mclntyre et al. 2011; Aina et al. 2011). Likewise, students need reading skills to analyze and comprehend the plethora of knowledge and facts available through the internet and other media (Vacca et al., 2005).

Elley (1991) proved that Grades 1-3 pupils, who carried out reading in English in Singapore, were 10\% more likely to perform well in the National Exams.

Given the role of English language, appropriate teaching of reading skills remains important if communicative competence is to be realized. According to Gauther and Lawson (2004) instruction of reading skills depends on the availability, quality and utilization of 
relevant instructional resources and the skill of the teacher. This is because instructional resources facilitate the understanding of difficult concepts as well as the teaching and learning of the reading skills. More so, the resources make it easier for learners to follow, understand and retain content of the lesson (Gamble, 1984; cited in Mubichakani and Koros, 2014).

The argument above implies that failure to provide instructional resources may impact on meaningful teaching and learning of English reading skills. Twoli et al. (2007) support this view by arguing that the teacher needs to select and use a wide variety of instructional resources when teaching to take care of individual differences in class. This is because the resources make the entire teaching and learning processes complete and functional. Sadly, the provision of instructional resources for teaching English reading skills has received little attention. Chepkurui (2004) and Onchera (2013) found out that many schools are not able to provide a variety of instructional resources needed for English instruction. Therefore, in order to improve the teaching and learning of English reading skills, teachers ought to utilize relevant instructional resources. It is for this reason that the researchers sought to find out the availability and use of instructional resources for the instruction of English reading skills in secondary schools in Kenya.

\section{Study objectives}

The main purpose of this study was to explore the availability and use of instructional resources for teaching and learning of English reading skills and examine the correlation between instructional resources and learning of English reading skills.

\section{Literature review}

\section{Availability of reading resources}

The development of English reading skills depends on many factors and among them is the availability and use of appropriate instructional resources. Okwara et al. (2009) observe that availability of essential instructional resources is a condition ideal for effective teaching of reading skills. They argue that when instructional resources in a school are inadequate in numbers, it generates enormous reading problems. Thus it is the prerogative of the teachers of English language to make instructional resources an integral part of their instructional process (Minae, 2004; N'Namdi 2005; Lindsay and Knight, 2007). Okwako (1994) cited in Ambuko (2013) support this view by arguing that availability of reading resources is a crucial aspect in language learning. He notes that a student will require a variety of reading material.
Junias (2012) conducted a study on Factors affecting the teaching of English reading skills in a second language of grade 3 learners and established that insufficient reading resources, poor teaching methods, insufficient teachers' and learners' interactions and overcrowded classrooms were significant factors that made the teaching of reading skills unsuccessful.

Her study gives some insight to the current research especially in looking at the availability and use of instructional resources in the teaching and learning of English reading skills. Previous studies in East African countries reveal a great scarcity of reading instruction materials in schools. Mwanamukubi (2013) investigated challenges faced by teachers when teaching reading skills to learners with reading difficulties. Her study established that the main challenges teachers faced were inadequate teaching and learning materials. Based on these findings, the study recommended that schools should provide adequate learning and teaching materials. Another study by Nalusiba (2010) investigated the Strategies for the development of a reading culture in Uganda primary schools and concluded that inadequate reading resources inhibited the reading culture among the pupils. Similarly, Mberia (2002) and Wangui (2012) found out that instructional resources for English reading skills are inadequate in most schools both in terms of quantity and variety. They observe that in most schools basal and supplementary readers are not used; not to mention the libraries. It is therefore on these grounds that the present study wanted to establish the availability and use of instructional resources for teaching English reading skills in secondary schools in Kenya.

\section{Importance of varying reading resources}

Junias (2009) points out that a good linguistic classroom environment plays a very important role in contributing to the development of reading skills. This argument is supported by Hurd et al. (2006) who advocate for use of a variety of instructional resources to teach reading skills. According to them learners should be provided with a variety of narrative and expository books which reflect the interests of the learners.

The use of a variety of reading resources to teach English reading skills is more significant and motivating for learners. Some of the English reading resources include but are not limited to library books, newspapers, flash cards, periodicals, journals, magazines, printed materials, charts, recordings, videos, pictures, online resources and all technology-based resources (KIE, 2002; Sanderson, 2005; Namata , 2010; Andima, 2013). Sacha (2006) further advices teachers of English language to use internet material to teach English reading skills. He asserts that whereas newspapers and any other printed material date very quickly, the internet 
is continuously updated, more visually stimulating as well as being interactive, therefore promoting a more active approach to reading rather than a passive one. In fact, Grimshaw et al. (2007) did a study which proved that when readers utilize e-book resources, their reading skills improved a great deal. Consequently, this study was necessary to fill the knowledge and literature gaps regarding the correlation of instructional resources and learning of English reading skills.

As noted in the literature review, studies have indicated how various instructional factors facilitate the learning of English reading skills. The studies did not however, isolate the availability and use of instructional resources for teaching and learning of English reading skills. There are hardly any studies on the influence of instructional resources on the learning of English reading skills in Teso North Sub County. It is in view of these gaps that the current study was conducted.

\section{Limitations of the study}

This study was limited by scope on public secondary schools and nature of data collected which was mainly based on opinions and this kind of data is bound to be subjective. Some respondents were hesitant to give information and they were therefore assured that their responses would be held confidential.

\section{RESEARCH METHODOLOGY}

This study was carried out in public secondary schools in Teso North Sub County, Busia County of Kenya. Like many other parts of Kenya, many secondary school learners are not proficient in English reading skills. Between 2010 and 2014 the sub county has consistently posted poor results in English at the Kenya Certificate of Secondary Education (Omuna, 2015). This justified the selection of the sub county for this study. The study employed a mixed method design which employed both qualitative and quantitative methods to explore the availability and use of instructional resources for teaching and learning English reading skills in public secondary schools in Teso North Sub County. This was considered appropriate because it enabled the triangulation of results which ensured that the strengths of one method overcome the weaknesses of the other method thus strengthening quality and reliability of the findings. Mugenda and Mugenda (2003) observe that both methods supplement each other in that qualitative approach provides the in-depth explanations while the quantitative approach provides the hard data needed to meet required objectives and to test hypotheses. The population from which the sample for this study was drawn consisted of 26 public secondary schools, 59 teachers of English language and all the 1625 form three students. Stratified sampling and simple random sampling techniques were used to select 20 school, 40 teachers and 400 form three students. The data was collected using questionnaires for students, interview schedule for teachers and an observation checklist to observe and record classroom interaction between the teacher and the learner. These research instruments were developed by the researchers based on the research objectives. The questionnaire comprised of structured and unstructured questions and was made up of two sections. In section I, general information about the student was sought. In section II, specific information about availability and use of instructional resources was sought. The researchers administered the questionnaires in person to 400 students for a maximum of 40 minutes per student and collected them. The responses were used to analyze data quantitatively. Interviews were conducted informally with the teachers using structured questions. The teachers' interview schedule consisted of two sections. Section I consisted of general information about teacher while section II sought information on the availability and use of instructional resources. The responses were used to analyze data qualitatively. The interviews took forty minutes for every teacher. Classroom observation was done only once in each of the schools sampled for this study and each observation session lasted for a period of 40 minutes. Validity and reliability of instruments was established through careful selection of items to be responded to, piloting and expert review of the instruments. A test-retest method was employed to test for reliability of the instruments before administration. After the scores of the first test and the second test were correlated, a correlation coefficient of 0.84 was obtained.

\section{Data analysis}

This was done using both descriptive and inferential statistics. Descriptive analyses (percentages and frequencies) were used to summarize and describe the characteristics of the sample population while inferential statistics were used to make deductions and generalizations about the whole population. The results are presented in form of tables, and figures. Data from interview schedule was reported using direct quotations from the teachers.

Chi-square, pair wise correlation analysis and logistic regression analysis are used to determine whether there is a significant association between the independent variable (dictionaries, textbooks, class readers, newspapers, internet material, encyclopedia and wall charts) and dependent variable (the English reading skill) so that teachers can put more emphasis on them. Regression analysis was pursued for variables that were 
Table 1: Availability of Instructional Resources for English reading Skills

\begin{tabular}{lcccccc}
\hline \multirow{2}{*}{$\begin{array}{l}\text { Instructional } \\
\text { resources }\end{array}$} & \multicolumn{2}{c}{ Available } & \multicolumn{2}{c}{ Not available } & \multicolumn{2}{c}{ Total } \\
\cline { 2 - 7 } & Frequency & $\%$ & Frequency & $\%$ & Frequency & $\%$ \\
\cline { 2 - 7 } Dictionary & 123 & 30 & 277 & 69.25 & 400 & 100 \\
Text books & 196 & 49 & 204 & 51 & 400 & 100 \\
Class readers & 126 & 29.25 & 274 & 68.5 & 400 & 100 \\
News papers & 122 & 30.5 & 278 & 69.5 & 400 & 100 \\
Internet & 30 & 7.5 & 370 & 92.5 & 400 & 100 \\
Encyclopedia & 49 & 12.25 & 351 & 87.75 & 400 & 100 \\
Wall charts & 147 & 36.75 & 253 & 63.25 & 400 & 100 \\
\hline
\end{tabular}

Source: Field data (2014) $n=400$

significantly correlated with the dependent variable at $p<$ 0.05 level of significance.

\section{FINDINGS AND DISCUSSIONS}

The study involved 400 students (192 were male while 208 female). Majority of the students $(62.5 \%)$ were aged 15-17 years. On the other hand, 40 teachers were involved where $24(60 \%)$ were male and $16(40 \%)$ were female. Twenty five $(62.5 \%)$ teachers were holders of Bachelor of Education degree. Six (15\%) teachers were holders of Diploma in Education and one (2.5\%) had a Doctorate in Education while $2(5 \%)$ had a master of Education degree. Furthermore, $1(2.5 \%)$ teacher was an ' $A$ ' level graduate while $4(10 \%)$ had an 'O' level certificate.

\section{Availability of instructional resources}

The first objective of this study sought to establish the availability and use of instructional resources for teaching English reading skills in secondary schools. The data was obtained by means of students' questionnaires. Table 1 shows the frequency of availability.

From Table 1, it is evident that $196(49 \%)$ of the respondents said that textbooks are the most available instructional resources followed by wall charts 147 $(36.75 \%)$, class readers $126(29.25 \%)$, dictionaries $123(30 \%)$, newspapers $122(30.5 \%)$, encyclopedia 49 $(12.25 \%)$, internet $30(7.5 \%)$. This is supported by the teachers interviewed. Respondent 5 blatantly said, "The government sends tuition fund to schools and we are expected to strictly adhere to the rules and regulations of procuring learning and teaching materials. When we place our orders we are expected to stick to the textbooks recommended by the ministry."

Respondent 31, agreed with this statement by adding, "Yeah, I agree. The present Ministry of Education approved list does not allow the purchase of other instructional materials that do not appear in the list." In addition, Respondent 14 said, "In most cases, just a few copies of reading materials which are categorized as non- textbook reading materials commonly known as class readers are listed in the approved list of school books for pleasure reading." This confirms a finding by Mucai (2013) who reported that resources such as textbooks and library services were largely inadequate in almost all secondary schools in Kenya.

Results of the observation revealed that 8 schools did not have a variety of instructional resources in place. It was observed that the teachers in school 1,2,3,5,6,8,9 and 10 relied on English text books such as Excelling in English Book 3, New Integrated English Book 3 and Head Start Secondary English Book 3 when teaching. This observation agreed with the students' responses given in the questionnaire as well as the teachers' responses during the interviews. This finding is consistent with Wandera (2012) who found out that the text book was the most used material during the English language lessons in secondary schools in Nairobi. She observed that other supplementary materials were rarely used if at all.

\section{Correlation between instructional resources and learning of english reading skills}

The second objective sought to establish if there was a correlation between use of instructional resources and learning of English reading skills. The analysis involved use of inferential statistics involving multivariate techniques. The null hypothesis being tested was: HO: There is no statistically significant relationship between instructional resources and the learning of English reading skills. The significance level was set at $p<0.05$. Chi-square test was first used to test the null hypothesis. The results are as follows: 


\section{Dictionary and learning of english reading skills}

The test yielded a result of $x^{2}=4.0064, p=0.045$, Cramer's $V=0.1001$. The researchers rejected the null hypothesis at the $p<0.05$ level of significance and concluded that use of dictionaries had a significant relationship with learning of English reading skills. Cramer's V value (0.1001) however indicated a weak relationship. This finding is consistent with (Caleb and Yuko 2011) who found out that dictionary use increases learning of reading skills.|

\section{Text books and learning of english reading skills}

The test yielded a result of $X^{2}=8.8035, P=0.003$, Cramer's V $=0.1484$. Hence the researchers rejected the null hypothesis at the $p<0.05$ level of significance and concluded that textbooks had a significant relationship with learning of English reading skills. This finding is in agreement with the findings of Hurd et al. (2006) who pointed that text book provision is a significant factor in the success of any literacy program.

\section{Class readers and learning of english reading skills}

The test yielded a result of $X^{2}=7.2879, P=0.007$, Cramer's $V=0.1350$. The researchers rejected the null hypothesis at the $p<0.05$ level of significance and concluded that use of English class readers had a significant relationship with learning of English reading skills.

\section{Newspaper and learning of english reading skills}

The chi-square test results was $x^{2}=2.7868, P=0.045$, Cramer's V $=0.0835$. Hence researchers rejected the null hypothesis at the $p<0.05$ level of significance and concluded that there was a significant relationship between use of newspaper and learning of English reading skills. This finding is consistent with the findings by Namata (2010) who found newspapers improve reading skills.

\section{Internet and learning of english reading skills}

The chi-square test results were $x^{2}(1)=.0655, p=$ 0.008 , Cramer's $V=.0128$. The results show that there was significant relationship between use of internet services and the learning of English reading skills. Hence the researchers rejected the null hypothesis at the $p<$ 0.05 level of significance. This finding is in agreement with that of Grimshaw et al. (2007) and Chin-Neng (2013) found out that reading skills are significantly higher for electronic book (e-book) readers.

\section{Encyclopedia and learning of english reading skills}

A Chi-square test performed to establish the relationship between the dependent variable and the independent variable yielded a test result of Pearson $X^{2}(1)=5.3724$, $p=0.020$, Cramer's V $=0.1159$. The researchers rejected the null hypothesis at the $p<0.05$ level of significance and concluded that there was significant relationship between use of encyclopedia and learning of English reading skills.

\section{Wall charts and learning of english reading skills}

The test result of $x^{2}=1.2830, p=0.257$ and Cramer's $V=0.0566$. The researchers failed to reject the null hypothesis at $p<0.05$ level of significance and concluded that there was no significant relationship between use of wall charts and learning of English reading skills. Generally, the chi square results indicate that there is a strong correlation between instructional resources with the acquisition of English reading skills. The null hypothesis that there is no statistically significant relationship between instructional resources and learning of English reading skills is therefore rejected.

\section{Pair wise correlation between instructional resources and english reading skills}

Despite having done a Chi-square test to establish the relationship between the dependent and the independent variable, the researchers further performed a pair wise correlation analysis between the two variables to establish whether there was a significant correlation between them. The results are presented on Table 2 .

The results in Table 2 show that there was a significant positive correlation $(p<0.05)$ between textbooks $(p=0.0000)$, class readers $(p=0.0000)$, Newspapers $(p=0.0484)$, internet $\quad(p=0.0000)$, encyclopedia $(p=0.0000)$ and the acquisition of English reading skills. The results indicate that there is a strong correlation between instructional resources and the learning of English reading skills. The null hypothesis that there is no statistically significant relationship between instructional resources and acquisition of English reading skills is therefore rejected. The argument that could be advanced for this is that when teachers vary instructional resources learners stand a better chance of learning reading skills. 
Table 2: Correlation between Instructional Resources and English Reading Skills

\begin{tabular}{lcccccccc}
\hline Variables & $\mathbf{1}$ & $\mathbf{2}$ & $\mathbf{3}$ & $\mathbf{4}$ & $\mathbf{5}$ & $\mathbf{6}$ & $\mathbf{7}$ & $\mathbf{8}$ \\
\hline \multirow{1}{*}{1} & 1.0000 & & & & & & & \\
& 0.0468 & 1.0000 & & & & & & \\
2 & 0.3506 & & & & & & & \\
& $\mathbf{0 . 2 9 7 2 ^ { * }}$ & 0.0946 & 1.0000 & & & & & \\
3 & 0.0000 & 0.0587 & & & & & & \\
& $\mathbf{0 . 2 4 0 8}^{*}$ & 0.0380 & $0.4334^{*}$ & 1.0000 & & & & \\
4 & 0.0000 & 0.4490 & 0.0000 & & & & & \\
& $\mathbf{0 . 0 9 8 8}^{*}$ & $0.4058^{*}$ & 0.0458 & 0.0300 & 1.0000 & & & \\
5 & 0.0484 & 0.0000 & 0.3605 & 0.5491 & & & & \\
& $0.2899^{*}$ & $0.1188^{*}$ & $0.1766^{*}$ & $0.2156^{*}$ & $0.2031^{*}$ & 1.0000 & & \\
6 & 0.0000 & 0.0175 & 0.0004 & 0.0000 & 0.0000 & & & \\
& $0.2282^{*}$ & $0.3955^{*}$ & $0.2592^{*}$ & $0.1078^{*}$ & $0.2328^{*}$ & $0.2989^{*}$ & 1.0000 & \\
7 & 0.0000 & 0.1842 & 0.2734 & 0.0000 & 0.0000 & 0.0000 & & \\
& 0.0950 & $0.1888^{*}$ & $0.2279^{*}$ & 0.0859 & -0.0094 & $0.1373^{*}$ & $0.3320^{*}$ & 1.0000 \\
& 0.0575 & 0.0001 & 0.0000 & 0.0862 & 0.8513 & 0.0000 & 0.0000 & \\
\hline
\end{tabular}

* Correlation is significant at $(p<0.05)$ level

Table 3: Logistic Regression for instructional resources and reading skills

\begin{tabular}{lcccccc}
\hline Reading skills & Odds ratio & Std. Err. & $\mathbf{Z}$ & $\mathbf{P}>|\mathbf{z}|$ & [95\%conf. & Interval] \\
\hline Textbooks & 2.290343 & .6799611 & 2.79 & 0.005 & 1.279954 & 4.098328 \\
Class readers & 1.159475 & .340356 & 0.50 & 0.614 & .652224 & 2.061227 \\
Newspapers & 1.618149 & .5151869 & 1.51 & 0.131 & .8669874 & 3.020122 \\
Internet & 4.697851 & 2.516721 & 2.89 & 0.004 & 1.643977 & 13.42464 \\
Encyclopedia & 2.298697 & .9430328 & 2.03 & 0.042 & 1.028677 & 5.136702 \\
\hline
\end{tabular}

$N=400, \operatorname{LR}^{2}(2)=86.03$, prob $>X^{2}=0.0000$ pseudo $R^{2}=0.1821$ log likelihood $=-193.21694$

\section{Regression Analysis for Instructional Resources and English Reading Skills}

Logistic Regression analysis was used to analyse only those independent variables that were significantly correlated with the dependent variable at $p<0.05$ level of significance. The logistic regression analysis results are presented in Table 3.

The findings presented in Table 3 indicate that the odds of acquiring English reading Skills increased by 4.69 times (or $4.69-1 * 100=369 \%$ ), $p=0.0004$ at $95 \%$ confidence level when internet is used. This finding is similar to that of Sacha (2006) who notes that internet is a modern day authentic material for teaching English reading skills. Internet is continuously updated, more visually stimulating as well as being interactive, therefore promoting a more active reading. Similarly, Grimshaw et al. (2007) note that e-books aid in the comprehension of reading and enhance learning of reading skills.

The odds of learning English reading skills increased by 1.15 times (or $1.15-1 * 100=15 \%$ ), $p=0.614$ at $95 \%$ confidence level when class readers are used. The odds of learning English reading skills increases by 1.61 times (or $1.61-1 * 100=61 \%$ ), $p=0.131$ at $95 \%$ confidence level when newspapers are used. The odds of learning reading skills increase by 2.29 times (or $2.29-1 \times 100$ $=129 \%), p=0.042$ at $95 \%$ confidence level when the encyclopedia is used. While the odds of learning English reading Skills increased by 2.29 times (or $2.29-1 * 100=$ $129 \%), p=0.005$ at $95 \%$ confidence level when textbooks are used.

\section{CONCLUSIONS AND RECOMMENDATIONS}

The results of this study provide evidence that at the secondary school level, instructional resources are available. However some resources are less adequate than others. Text books are the most available instructional resources for teaching English reading skills. The least available instructional resources are: internet material, class libraries and Magazines. The study notes 
that teachers are still conservative, relying mostly on students' text books to teach English reading skills. The study established that use of instructional resources has a significant relationship with how often students learn English reading skills. Some instructional resources have more value than others in terms of their input.

Thus in order to improve the learning of English reading skills, teachers need to use a variety of instructional resources to support those which are already available.

In light of the above findings, the study recommends that it is highly essential to provide adequate and varied instructional resources for teaching and learning English reading skills at secondary school level. Instructional resources such as the internet material, newspapers, encyclopedias and class readers in addition to text books can be used to promote the teaching and learning of English reading skills.

\section{REFERENCES}

Aina AJ, Ogungbeni JI, Adigun JA, Fatiu AA, Ogundipe TC (2011). Poor reading habits among Nigerians: the role of libraries. Library philosophy and practice 2011://unllib.unl.edu/LPP/.

Ambuko BF (2013). Selection and use of media in teaching Kiswahili language in secondary schools in Kenya. Intl. J. of Information and Communication Technology Res. 3(1): 12-18

Andima GM (2013). Teaching of reading to early grade readers: Implications for the Kenyan primary school teacher. Elixir International Journal. htt://www. elixirpublishers.com.

Caleb P, Yuko M (2011). The effect of lexical coverage and dictionary use on 12 reading comprehension. The reading matrix 11(3): 209211

Carell PL, Devine J, Eskey DE (1998). Interactive approaches to second language reading. Cambridge: CUP.

Chepkurui J (2004). The impact of availability of educational resources on pupils' cognitive achievement in public primary schools in Bureti District, Rift Valley province. Unpublished MED report, University of Nairobi, Kenya.

Chin-Neng C (2013). The effects of extensive reading via e-books on tertiary level EFL students' reading attitude, reading comprehension and vocabulary: The Turkish online J. of educational technology 12(2): 122-129.

Elley W (1991). Acquiring literacy in a second language: the effect of book-based programs. Language Learning, 41(3), 375-411.

Gamble KT (1984). Communication works. New York. Random House Inc.

Gauther R, Lawson A (2004). Teaching and learning mathematics: The report of the expert of the expert panel on mathematics in Grade 4 to 6 in Ontario.www.edu.gov.on.ca/eng/document/report

Gove A, Wetterberg A (Eds.) (2011). The early grade reading assessment: Applications and interventions to improve basic literacy. RTI International. Research Triangle Park.

Grimshaw S, Dungworth N, McKnight C, Morris A (2007). Electronic books: Children's reading and comprehension. British Journal of Educational Technology, 38(4): 583-599. doi: 10.1111/j.14678535.2006.00640.

Hurd S, Dixon M, Oldman J (2006). Are low levels of book spending in primary schools jeopardizing literacy strategy? Curriculum J. 17 (1): 73-88.

Junias R (2009). Factors affecting the teaching of English reading skills in a second language of grade 3 . Unpublished M.Ed Thesis. Ongwediva: Namibia.
Kenya Institute of Education (2002). Secondary Education syllabus Vol (5) Kenya: Nairobi: KI E.

Lindsay C, Knight $P$ (2007). Learning and teaching English. New York: Oxford University Press.

Maingi JM (2015). Language teachers' perceptions and practices in enhancing learners' strategy use for reading proficiency in selected secondary schools in Kenya. Unpublished PhD thesis Kenyatta University: Nairobi.

Mberia HK (2002). A survey of the teaching of reading in English in lower primary classes of Gatundu division in rural Thika district. Unpublished MA Thesis. Kenyatta University: Nairobi.

Mclntyre E, Hulan N, Layne V (2011). Reading instruction for diverse classrooms: Research-based, culturally responsive practice. New York and London: Guilford Press.

Minae MI (2004). Selection and utilization of instructional resources by teachers of English in selected schools in Murang'a District. Unpublished Med Thesis. Nairobi: Kenyatta University.

Mubichakani MJ, Koros CS (2014). The availability, adequacy and improvisation and the use of instructional resources for teaching mathematics in secondary schools in West Pokot District, Kenya J. of Edu. and Practice Vol.5, No.20

Mucai EW (2013). Availability and utilization of educational resources in influencing students' performance in secondary schools in Mbeere South, Embu County, Kenya. Unpublished M.ED. Thesis. Kenyatta University: Nairobi.

Mugenda MO, Mugenda GA (2003). Research methods, qualitative and quantitative approaches. Nairobi: Acts Press.

Mwanamukubi L (2013). Reading difficulties in grade six learners and challenges faced by teachers in teaching reading. Case of Chadiza and Chipata districts Zambia. Unpulished MA Thesis University of Zambia.

Nalusiba P (2010). Strategies for the development of a reading culture in Uganda primary schools: case studies of four selected universal primary education schools in Kampala district. Unpublished M.Sc Thesis Makerere University.

Namata W (2010). Newspapers as tools of literacy in Uganda a case study of daily monitor's newspapers in education programme addressing literacy-related issues in Uganda's primary education. Unpublished M.Phil. Thesis. (IMK) University of Oslo. Norway.

N'Namdi KA (2005). Guide to teaching reading at the primary school level. UNESCO: United Nations Educational.

Okwara MO (2009). Towards a model of integrated English language curriculum for secondary schools in Kenya. Educational Research and Review 4(5): 301-309.

Omuna MO (2015). Influence of pedagogy on acquisition of English reading skills in secondary schools in Teso North Sub County, Kenya. Unpublished Masters' Thesis University of Kabianga, Kericho Kenya.

Onchera PO (2013). The pedagogical hinderances to oral communication skills in English in Kenya: A case of secondary schools in Kisii County. Edu. Res. vol. 4 (7):536-542.

Sacha $A B$ (2006). The use of authentic materials in the teaching of reading. The Reading Matrix, 6 (2): 305-347.

Sanderson P (2005). Using newspapers in the classroom. Cambridge: Cambridge University Press

Twoli N, Maundu J, Muindi D, Kiio M, Kithinji C (2007). Instructional methods in education. Nairobi: KIE

Vacca R, Vacca J (2005). Content area reading - Literacy and learning across the curriculum. USA: Pearson Education.

Wandera S (2012). Effectiveness of teaching methods In English language on acquisition of English language skills in public secondary schools in Nairobi County, Kenya.Un published Med Project. University of Nairobi, Kenya.

Wangui KM (2011). Influence of learning environment on reading comprehension among pre-unit children in Kikuyu Division Kiambu County. Unpublished M.Ed Thesis University of Nairobi. 
008 Educ. Res

\section{Appendix}

Appendix 'A': Narration of independent variables

\begin{tabular}{lc}
\hline Variable & Variable Description \\
\hline 1 & Dictionary \\
2 & Text books \\
3 & Class readers \\
4 & Newspapers \\
5 & Internet \\
6 & Encyclopaedia \\
7 & Wall charts \\
\hline
\end{tabular}

\section{Appendix 'B': students' questionnaire (SQ)}

Dear student,

The purpose of this research is to find out Availability and use of Instructional Resources for Teaching and Learning of English Reading Skills in Secondary Schools in Teso North Sub County, Kenya. Please answer all questions by putting a tick $(\sqrt{ })$ against the information most applicable to explain your response.

\section{Section I: Background information}

1. What is your age bracket? $15-17$ years [ ] above 17 years [ ]

2. What is your gender? Male [ ] Female [ ]

\section{Section II: Availability and Adequacy of Instructional Resources}

3. Below are examples of the instructional resources. Which ones are available in your school? Tick $(\sqrt{ })$ against each item to indicate the level of availability of resources.

\begin{tabular}{|c|c|c|c|c|}
\hline Instructional Resources & Available and adequate & Available and & Not adequate & Not Available \\
\hline \multicolumn{5}{|l|}{ Dictionary } \\
\hline \multicolumn{5}{|l|}{ English text books } \\
\hline \multicolumn{5}{|l|}{ English class readers } \\
\hline \multicolumn{5}{|l|}{ News papers } \\
\hline \multicolumn{5}{|l|}{ Internet material } \\
\hline \multicolumn{5}{|l|}{ Encyclopedia } \\
\hline Wall charts & & & & \\
\hline
\end{tabular}

\section{Section III: Use of instructional resources}

4. Put a Tick $(\sqrt{ })$ against each instructional resource below to show how often the teacher uses them when teaching English reading skills.

\begin{tabular}{|c|c|c|c|c|}
\hline Instructional resources & Frequently & Occasionally & Rarely & Never \\
\hline \multicolumn{5}{|l|}{ Dictionary } \\
\hline \multicolumn{5}{|l|}{ Text books } \\
\hline \multicolumn{5}{|l|}{ Class readers } \\
\hline \multicolumn{5}{|l|}{ Newspapers } \\
\hline \multicolumn{5}{|l|}{ Internet material } \\
\hline \multicolumn{5}{|l|}{ Encyclopedia } \\
\hline Wall charts & & & & \\
\hline
\end{tabular}




\section{Appendix 'C': Teachers' interview schedule}

\section{Section I: Demographic Data}

\section{Male [ ] Female [ ]}

2. State your highest academic qualification:

i) 'O' Level

ii) 'A' Level

iii) Diploma in Education

iv) Degree (B. Ed)

v) $M E d$ MA

vi) Doctorate

(B. A)

$[\quad]$

[ ]

[ ] $]$

$\left[\begin{array}{ll}{[} & ] \\ {[} & ]\end{array}\right]$

$\left[\begin{array}{ll}{[} & ]\end{array}\right]$

\section{Section II: Instructional resource availability and adequacy}

3. What are the most available instructional resources for teaching English reading skills in your school?

4. What is your opinion on the adequacy of the available instructional resources?

5. From which instructional resources do you use to teach English reading skills?

6. What influences your choice of these instructional resources?

7. How do you ensure that students understand the reading materials?

\section{Appendix ' $D$ ': classroom observation checklist}

Name of School class Topic

\begin{tabular}{|c|c|c|c|}
\hline \multirow[t]{2}{*}{ Aspects to be observed } & \multicolumn{3}{|c|}{ OBSERVATIONS } \\
\hline & \multirow[t]{2}{*}{ Available and in use } & \multirow{2}{*}{ Available \& Not in use } & \multirow[t]{2}{*}{ Not available } \\
\hline Instructional resources used to teach reading & & & \\
\hline \begin{tabular}{l|l} 
Dictionary \\
\end{tabular} & & & \\
\hline Text book & & & \\
\hline Class readers & & & \\
\hline Newspapers & & & \\
\hline Internet Material & & & \\
\hline Encyclopedia & & & \\
\hline Wall charts & & & \\
\hline
\end{tabular}

